\title{
O MISSIONÁRIO E O CORONEL: UMA ICONOGRAFIA DO MÉDICO-MISSIONÁRIO GEORGE BUTLER
}

\section{THE MISSIONARY AND THE COLONEL: A ICONOGRAPHY OF THE MEDICAL MISSIONARY GEORGE BUTLER}

Rogério de Carvalho Veras ${ }^{1}$

\section{RESUMO}

Empreendemos um estudo sobre a inserção do protestantismo no Nordeste do Brasil por meio da biografia do médico e missionário protestante George William Butler. No âmbito de uma perspectiva micro-analítica, objetivamos compreender como ele dá sentido às suas relações sociais e ao mundo à sua volta - o Nordeste no alvorecer do século XX - bem como essa sociedade recepcionou um indivíduo portador de uma nova religiosidade. Percebendo as limitações das fontes escritas (relatórios missionários) para tais propósitos de pesquisa, buscamos uma análise iconográfica das fotos divulgadas pelo missionário e sua esposa, por meio de sua instituição: a Presbyterian Church in the United States (PCUS). Pensamos essas imagens como uma via de acesso às representações sociais que cercam as relações entre um protestante, originário do sul dos Estados Unidos, e a cultura local, por meio da investigação da produção, circulação e apropriação dessas imagens. As fotografias, cotejadas com outras fontes escritas, permitiram-nos recompor a dimensão ideológica das imagens e o esforço de manutenção do poder, em meio aos avanços e recuos da transição secularizadora e do capitalismo anglo-saxão, aliando protestantes e latifundiários, no interior pernambucano.

Palavras-chave: Iconografia. Protestantismo. Nordeste.

${ }^{1}$ Doutorando em História, UNESP - Assis. Professor da Universidade Federal do Maranhão. E-mail: rogerioveras14@gmail.com. 


\begin{abstract}
We undertake a study about the beginning of Protestantism in the Northeast of Brazil through the biography of George William Butler, doctor and protestant missionary. From the point of view of a micro-analytical narrative, we aim to understand how he gives meaning to his social relations and to world around him - the Northeast at the dawn of the twentieth century - as well as the society welcomed an individual with a new religiosity. Realizing the limitations of written sources (mission reports) for such research purposes, we seek an iconographic analysis of the photos published by the missionary, and his wife, through their institution Presbyterian Church in the United States (PCUS). We think these images as a means of access to social representations concerning the relationship between a Protestant, who comes from southern United States, with the local culture, through the investigation of the production, circulation and reception of these images. The photographs, collated with other written sources, enabled us to rebuild the ideological dimension of images and the effort to maintain powers, amid the ebb and flow of secularizing transition and anglo-saxon capitalism, uniting both Protestant and landowners of Pernambuco's territory.
\end{abstract}

Keywords: Iconography. Protestantism. Northeast Brazil. 


\section{Introdução}

O personagem George Butler viveu no Maranhão e em Pernambuco no período da transição republicana (1883-1919). O historiador Émile G. Léonard (1981, p. 97 e 98) faz alusão a sua atuação no Maranhão, onde alcançava as classes mais abastadas de São Luís, trazendo para sua Igreja pessoas de influência na sociedade, como aquelas ligadas aos membros da Junta Governativa, após a República proclamada. Butler estendeu seu trabalho ao interior da província, margeando o Rio Itapecuru e Mearim. Esteve em cidades como Pedreiras, Rosário, Caxias, onde havia a instalação de fábricas têxteis com presença de norte-americanos, ingleses e outros europeus (MELO, 1990). Daí seguiu para Teresina, iniciando o protestantismo também na capital do Piauí.

Em São Luís, no ano de 1887, construiu um templo presbiteriano quando ainda as leis do Império proibiam este tipo de edificação ${ }^{2}$. No mesmo local até hoje permanece a $1^{\mathrm{a}}$ Igreja Presbiteriana de São Luís. A façanha da construção de um templo antes da proclamação da República foi para o seu principal biógrafo, Edijéce Martins Ferreira e também para a memória familiar, algo inédito no norte do Brasil ${ }^{3}$. Em Pernambuco, esteve de 1893-1919, onde continuou sua vocação de construtor de templos, agora do $1^{\circ}$ templo da Igreja Presbiteriana em Recife que era localizada na praça Joaquim Nabuco e em seguida, 1894, foi para região de Garanhuns e Canhotinho, onde construiu templos, um hospital e uma escola. Nesta funcionava também um curso de formação de novos pastores, transformando Garanhuns e Canhotinho em bases de expansão do protestantismo pelo norte do país. Na região, enfrentou uma epidemia de febre amarela, em 1897, tornando-se mais conhecido como médico do que pregador e

\footnotetext{
${ }^{2}$ Art. $5^{\circ}$ da Constituição do Império diz que “a religião Católica Apostólica Romana continuará a ser a do Império. Todas as outras serão permitidas com seu culto doméstico ou particular, em casas para isto destinadas, sem forma exterior de templo". É possível que devido essas restrições, os primeiros missionários do Nordeste tenham preferido deixar, em seus escritos, notícias de "fundação e organização de igrejas" (anteriores à de São Luís), que ocorriam já com os primeiros grupos de batizados, e não se referiam a existência de templos para suas reuniões.

${ }^{3}$ É significativo a memória da viúva de Butler, Mary Rena Hamphreys Butler, que lembrava com orgulho e certa hipérbole do feito do marido: "During his eight years stay in Maranhão, he had the honor of building the first Protestant Church in Brazil" [Durante seus oito anos no Maranhão, ele teve a honra de construir a primeira Igreja Protestante no Brasil] (Dr. George Butler by Mrs. Butler, s/d, p. 2. Arquivo da Presbyterian Historical Society, RG 360, series III).
} 
angariando a aliança de importantes famílias proprietárias e chefes políticos.

Um dos objetivos dessa pesquisa de inspiração micro-histórica é reconstituir a complexidade dos vínculos sociais deste personagem nas sociedades em que viveu. Tarefa nada simples de executar, principalmente considerando as especificidades das fontes da história do protestantismo. Os historiadores do protestantismo têm, como fontes principais, as cartas e os relatórios dos missionários enviados às suas instituições eclesiásticas. Nessas cartas-relatórios temos geralmente vozes já normalizadas pelo padrão cultural institucional, ou seja, na maioria das vezes, ocorre um tipo oficial de relato dos missionários a fim de convencer os seus mantenedores (os comitês de missões e os fiéis das igrejas de origem) do seu ativismo missionário e provável sucesso daquele empreendimento. Em meio a essa tônica triunfalista dos relatos, surgiram-nos inquietações, isto é, como seria possível ver os conflitos pessoais, as frustrações, os arrependimentos, em uma palavra, a vida desses missionários? Para o nosso biografado, como é possível encontrar suas percepções sobre esse chão social em que está pisando? Como ele interpretou e foi interpretado pelas sociedades em que viveu? Acrescente-se a isso os limites que temos de acesso às perspectivas dos atingidos pela ação desses missionários, ou seja, os novos fiéis dessas igrejas. Estes eram, em sua maioria, pessoas sem posse e prestígio, muitos, semianalfabetos. Assim, poucos conversos deixaram seu próprio testemunho escrito do que significava se tornar protestante e da relação com os pastores e missionários estrangeiros naquele contexto de inserção de uma nova religião.

Reconhecendo esses limites da documentação, procuramos superar o olhar condicionado pelos interesses institucionais dos missionários. Assim, pensamos trabalhar fontes ainda pouco apreciadas na historiografia do protestantismo no Brasil: as fotografias divulgadas pelos missionários em seus relatórios. Orienta-nos a ideia de que os sentidos da produção, circulação e apropriação das imagens ultrapassam os sentidos visados pelos missionários e nos revelam facetas das suas relações sociais que não foram explicitados nas fontes escritas. Dessa forma, tomamos duas fotografias divulgadas por George Butler e sua esposa, Rena Butler, considerando-as porta de acesso à complexidade de sua inserção no tecido social. 


\section{A narrativa por trás dos personagens}

No ano de 1916, o missionário e médico norte-americano George William Butler, já vivia há mais de 30 anos no Nordeste do Brasil. Há 20 anos tinha fixado residência no interior de Pernambuco, em Garanhuns e Canhotinho, localidades vizinhas no agreste Pernambucano, tradicional região da agricultura de exportação. E no início do século XX, ambas eram as últimas estações da estrada de ferro que ligava esta região ao porto de Recife, levando diversos produtos agrícolas, principalmente, algodão, açúcar e tabaco pelos trilhos da Great Western Railroad Company, uma companhia inglesa instalada na região desde $1901^{4}$.

Em 1885, a estrada de ferro alcançava Canhotinho e cerca de dez anos depois chegavam também os primeiros esforços missionários sob as ordens do "Presbitério de Pernambuco"5 - uma reunião com 5 missionários norte-americanos, dividindo territorialmente $\mathrm{o}$ Norte/Nordeste brasileiro ${ }^{6}$, que partiam para diferentes capitais com vistas a iniciar os esforços de evangelização em imensas áreas ${ }^{7}$. Contavam com ajuda de leigos, chamados de evangelistas, geralmente usados no serviço de colportor (venda de Bíblias e literatura evangelística protestante), principalmente para as viagens ao interior dos estados.

Foi utilizando-se dessa logística que depois de George Butler estabelecer-se em Garanhuns em 1995, o evangelista Vera Cruz avança a evangelização até Canhotinho. A narrativa posteriormente registrada

${ }^{4}$ GIESBRECHT, Ralph Mennucci. Estações Ferroviárias do Brasil. Disponível em: http://www.estacoesferroviarias.com.br/pernambuco/canhotinho.htm. Acesso em: 05/02/2015

${ }^{5} \mathrm{O}$ primeiro missionário a estabelecer-se em Garanhuns foi o escocês Henry John MacCall, em 1894, enviado pela Help for Brazil Mission, organização criada pelo médico e missionário Robert Reid Kalley que atuara no Rio de Janeiro em meados do século XIX. (VIEIRA, 2008, p. 128)

${ }^{6}$ Em 1885, a Missão (do Norte do Brasil) procedeu à distribuição dos missionários em toda a região Norte. A distribuição ficou assim estabelecida: Smith e Porter ficariam em Pernambuco; Wardlow iria para o Ceará; Garen, um dos novos obreiros da Missão, foi indicado para Alagoas e Butler para o Maranhão, onde deveria abrir novo trabalho. (FERREIRA, 1987, p. 30)

${ }^{7}$ Caso emblemático é o trabalho do Rev. William McQuown Tompson que de 19051908 era o único responsável pela assistência de igrejas que cobriam de Teresina a Manaus, passando por Belém e o interior de três estados Maranhão, Pará e Amazonas. (MATOS, 2004, p. 254). 
pela esposa de Butler, Dna. Mary Rena Humprey Butler ${ }^{8}$, recorda como desde o princípio na nova estação missionária fica claro a quem os missionários precisavam se aliar se quisessem, no mínimo, sobreviver naquelas paragens pouco amistosas para forasteiros de uma religião estrangeira.

A memória que se guardou desse primeiro contato é emblemática das percepções que os missionários americanos tinham dos desafios e aliados necessários no interior do Nordeste brasileiro. Nesta narrativa feita cerca de 20 anos depois dos fatos, conhecemos uma figura fundamental para o missionário George Butler em Canhotinho, o $\mathrm{Sr}$. Caetano Vidal, um dos coronéis locais, vejamos a narrativa:

After getting a foothold in Garanhuns he (Dr. Butler) decided to send Sr. Vera Cruz, a native worker, to Canhotinho, the next town of importance. He did not Known that the men of this town, with Sr. Caetano as leader, had sworn never to let one of the "new sect" enter there.

One day in his coffee field Sr. Caetano heard a great noise at the railroad station, and asking the cause of it was told that a man of the "New Sect" had come in on the train from Garanhuns, and that the people were stoning him. "Well, let me run and throw may stone, too", he said and picking up a big one, ran with all his might. Surely God must have met him on the way, for he told me afterwards that when he reached the station and saw an elderly man sitting with an open book in his hands, just waiting patiently for what would happen, his heart seemed to burst with pity, and walking up to Senhor Vera Cruz, he said "Get up and come with me". He answered, "Do you represent the authority of this place?" "No, I represent nothing," and poor Senhor Vera Cruz, thinking nothing but violence awaited him, said in his heart, "Lord, is it today?" He got up and Senhor Caetano led him through the town and up the hill to his home. A great crowd followed with stones in their hands and knives in their pockets, waiting to see what was to be done. As soon as Senhor Caetano reached the gates that led into his sitio, he pushed Senhor Vera Cruz inside, shut them, and facing the crowd with his back to the gates, said, "Men, this man is my guest and I shall defend him as long as I have strength, and behind me are my dogs, and behind my dogs are my guns."

When the crowd had dispersed he took Sr. Vera Cruz into his house and asked what he was there for and what he really came

\footnotetext{
${ }^{8}$ A narrativa está numa carta/relatório da Dna. Rena ao The Missionary Survey (um periódico mensal da Presbyterian Church in the United States - PCUS (esta Igreja Presbiteriana surgiu de uma cisão em razão da questão da escravidão durante a Guerra de Secessão, 1861-1865; ficou conhecida como a "igreja do sul") e publicada em julho de 1916. O principal objetivo do periódico era apresentar aos fiéis americanos a expansão dos seus trabalhos missionários pelo mundo.
} 
to do. He said he came to preach the gospel, the good news of salvation. Sr. Caetano told him if that was what he wanted to do, he could begin at once, and preach as long as he wanted to.

Well, he did preach, and people believed. When Dr. Butler went down a month later, there was a friend's house open to him and a little nucleus of believers ready to receive him." (The Missionary Survey, julho de 1916, p. 496 e 498). ${ }^{9}$

Apesar de longa, insistimos nessa narrativa porque ela se relaciona com as fotografias as quais nos propomos analisar neste artigo. As imagens que obtemos estão num livro publicado em 1917 pela Presbyterian Church in the United States (PCUS), escrito por Henry F. Williams, intitulado "In Brazil: the brazil missions of the Presbyterian Church in the United States". A primeira foto é do hospital construído em Canhotinho por Butler e a foto logo abaixo do Sr. Caetano Vidal dos Santos e George Butler. Na legenda da imagem, da publicação de 1917, a mesma história acima contada pela esposa de Butler para The Missionary Survey de julho de 1916. Segue as imagens:

\footnotetext{
${ }^{9}$ Depois de estabelecer uma posição em Garanhuns, ele (Dr. Butler) decidiu enviar o Sr. Vera Cruz, um obreiro nativo, para Canhotinho, a próxima cidade em importância. Ele não sabia que os homens desta cidade, tendo o Sr. Caetano como líder, tinham prometido nunca deixar um "nova-seita" entrar lá. Um dia em sua plantação de café o Senhor Caetano ouviu um grande barulho vindo da estação e perguntando a razão disto, foi-lhe dito que um homem da "Nova Seita" estava vindo no trem de Garanhuns e que o povo estava indo apedrejá-lo. "Bem deixe-me correr e jogar minha pedra também", ele disse e pegando uma bem grande, correu com toda sua força. Certamente, Deus deve o ter encontrado no caminho, pois ele contou-me mais tarde que quando ele chegou a estação e viu um ancião sentado com um livro aberto nas mãos, apenas esperando pacientemente pelo que aconteceria, seu coração pareceu encher-se de compaixão e indo em direção ao Senhor Vera Cruz ele disse "Levante-se e venha comigo". Ele respondeu "Você representa a autoridade deste lugar?". "Não, eu não represento nada" E pobre Senhor Vera Cruz pensando que nada menos que violência esperava por ele, disse em seu coração, "Senhor, é hoje?" Levantou-se e o Senhor Caetano conduziu-o pela cidade e subiram o morro para a sua casa. Uma grande multidão seguiu com pedras nas mãos e facas nos bolsos, esperando para ver o que iria ser feito. Assim que o Senhor Caetano chegou ao portão que levava para o seu sítio, ele empurrou o Senhor Vera Cruz para dentro, fechou os portões, de frente para a multidão e de costas para os portões disse, "Homens, este homem é meu hóspede e eu vou defendê-lo enquanto tiver forças, e atrás de mim estão meus cachorros, e atrás de meus cachorros estão minhas armas". Quando a multidão foi dispersa, ele levou o Sr. Vera Cruz para dentro de sua casa e perguntou pelo que ele estava lá e o que ele realmente veio fazer. Ele disse que veio pregar o evangelho, as boas-novas de salvação. O Sr. Caetano disse a ele que se era aquilo que ele queria fazer, que poderia começar logo e que pregasse pelo tempo que quisesse. Bem, ele pregou, e pessoas creram. Quando o Dr. Butler desceu lá um mês depois, havia uma casa amiga aberta para ele e um pequeno núcleo de crentes pronto para recebê-lo.
} 
FOTO 1: superior, Enoch's Hospital, Canhotinho

FOTO 2: inferior, George William Butler, à dir. e Sr. Caetano Vidal, à esq.

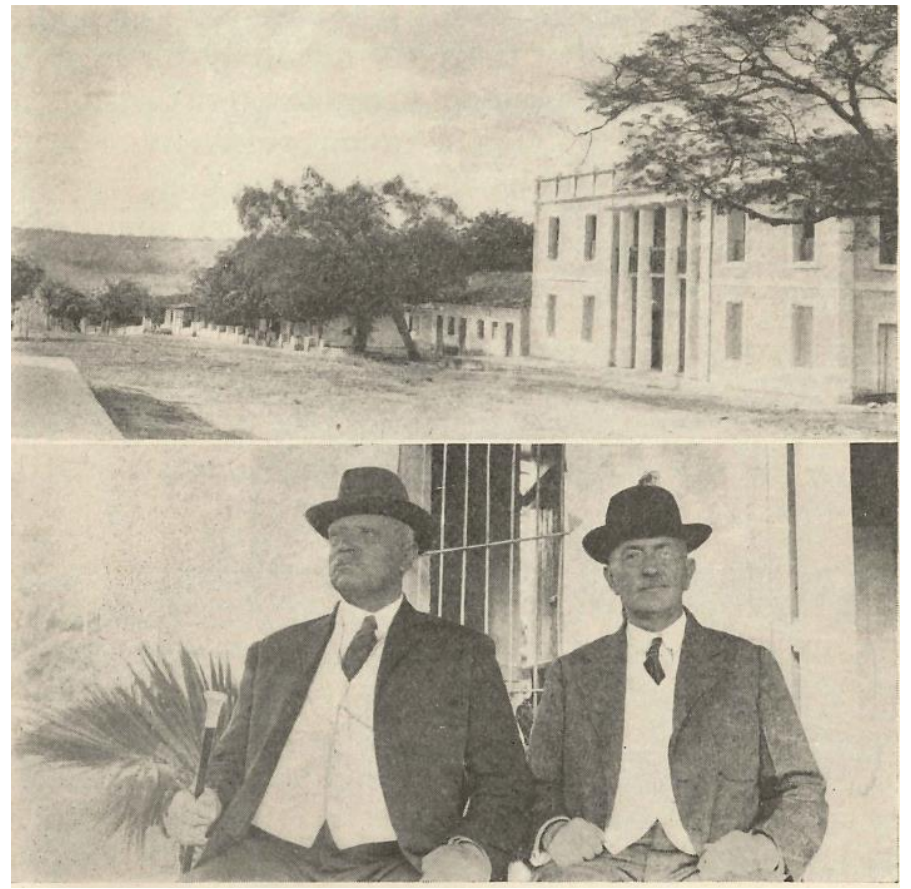

\section{As imagens nos bastidores (teoria e metodologia)}

Nossa proposta de análise destas imagens parte de nossas preocupações de pesquisa, basicamente como um missionário-médico dá sentido às suas relações sociais e ao mundo (alvo de sua missão) à sua volta e, o caminho inverso, como ele é percebido por estas mesmas pessoas. Nesse aspecto, as imagens podem ser uma via de acesso às representações sociais que cercam as relações entre um missionário norte-americano protestante e seus aliados do mundo rural pernambucano. Todavia, não queremos utilizá-las apenas como superação de uma lacuna da fonte escrita. Seguindo os ensinamentos de Ulpiano Menezes, abordamos a imagem enquanto capaz de provocar efeitos, produtora e mantenedora de sociabilidades e identidades, e de tornar empíricos projetos de organização e atuação do poder (MENEZES, 2003, p. 15). Na fórmula de John Tagg, não "o que se expressa", mas “o que se provoca” (Apud MENEZES, 2003, p. 30). 


\begin{abstract}
fornecer informações a uma questão do observador, qualquer que seja sua natureza tipológica, material ou funcional. É preferível, portanto considerar a fotografia (e as imagens em geral) como parte viva de nossa realidade social (...) O emprego de imagens como fonte de informação é apenas um dentre tantos (inclusive simultaneamente a outros) e não altera a natureza da coisa, mas se realiza efetivamente em situações culturais específicas, entre várias outras. A mesma imagem, portanto, pode reciclar-se, assumir vários papéis, ressemantizarse e produzir efeitos diversos (MENEZES, 2003, p. 29).
\end{abstract}

Com base nessas orientações buscamos um exercício de análise numa primeira aproximação das imagens, procurando controlar nossas deduções com informações fornecidas por outras fontes por nós conhecidas até o momento, como outros exemplares da The Missionary Survey e os relatos biográficos escritos pela Dna. Rena Butler após a morte do marido. Aspectos colocados por Menezes (2003) no estudo de imagens como sua produção, circulação e consumo/apropriação, compõem nossas preocupações metodológicas, a partir das quais propomos interpretar as imagens na sua dimensão de objeto manipulável, aberto a diversos sentidos e ressemantizações, relacionados a interesses específicos de diferentes atores sociais.

\title{
3. As imagens em cena
}

Como informamos, nosso primeiro contato com as imagens foi por meio da descoberta de um livro publicado em 1917 pela PCUS, de autoria de Henry F. Williams. Este livro foi-nos enviado pela Presbyterian Historical Society (PHS), instituição que atualmente guarda os documentos e livros relacionados às missões e missionários das igrejas presbiterianas estadunidenses que atuavam em diversas partes do mundo. De fato, apenas o trecho que se refere ao trabalho de George Butler em Canhotinho e no Maranhão foi-nos enviado, enquanto parte da documentação organizada sob o nome deste missionário. Nesse trecho também estão as fotos acima. Logo abaixo das fotos, as legendas: "CANHOTINHO (1) Enoch's Hospital (2) Sr. Caetano Vidal dos Santos and Rev. Geo. W. Butler, M.D"

Procuramos seguir trilhas que o texto vinculado às imagens nos dá a fim de melhor elucidar as questões a que nos propomos. Também utilizamos outras fontes, duas cartas de Dona Rena existentes nos arquivos da PHS e enviadas juntamente com esse livro. Estas cartas 
foram feitas após a morte de Butler ${ }^{10}$ (1919), portanto, posterior a publicada no The Missionary Survey, em 1916, mas ainda não conseguimos identificar as suas datas ${ }^{11}$. Procuramos elaborar um diálogo entre estes textos (fontes primárias e secundárias) e as imagens como recurso metodológico para extrair o máximo de informações que nos subsidiem a pensar tanto o circuito iconográfico (produção/circulação/consumo) quanto a imagem como produtora de efeitos sociais.

Logo no início, Henry F. Williams (1917, p. 36) afirma: “The history of the opposition to the gospel when first introduced in Canhotinho is well known"12. Em seguida, o autor começa a relatar os sucessos da missão em Canhotinho, seu crescimento numérico e o trabalho médico de Butler citando a construção de um hospital a partir de ofertas que Butler recebeu de um amigo metodista nos Estados Unidos, dando ao local o nome de Enoch's Hospital, em homenagem ao doador dessa construção. Este é, conforme a primeira legenda, o prédio que se destaca das demais construções na foto acima (foto 1).

Para a segunda foto (foto 2), o autor coloca mais informações sobre os personagens retratados. Após a legenda com os nomes, vem um pequeno texto em formato "antes e agora". No "antes" repete quase exatamente a história contada por Dona Rena em julho de 1916, ao The Missionary Survey, sobre a tentativa de apedrejamento do ancião, Sr. Vera Cruz, enviado por Butler a Canhotinho, e de como por providência (divina e) do Sr. Caetano Vidal ele foi poupado e teve início o primeiro núcleo de crentes na cidade, justamente na casa desse chefe local. O autor complementa essa narrativa com a inevitável conclusão: "The would be persecutor became, at once, the protector and savior of the elderly preacher"13. No "agora", Henry F. Williams coloca que "For twenty-one years Sr. Caetano has been a believer, a

\footnotetext{
10 No início do texto a autora, seguindo um padrão biográfico, coloca a data de nascimento e de morte do seu marido.

11 São as duas cartas sínteses da biografia e do trabalho missionário do falecido marido, descritas para perpetuar sua memória, intituladas: $1^{\text {a }}$ ) "Dr. George W. Butler by Mrs. Butler"; a 2 $2^{a}$ ) "Concerning Dr.Butler's Work by Mrs. Butler". Possivelmente, pelo tom padrão de relatório missionário, essas cartas foram feitas a pedido da PCUS a fim de registrar os esforços dos missionários em publicações futuras.

12 "A história da oposição ao evangelho quando introduzido pela primeira vez em Canhotinho é bem conhecida".

13 "O que seria perseguidor tornou-se, subitamente, o protetor e salvador do pregador idoso".
} 
church member, a staunch defender of the gospel, and loyal friend, and heroic defender of the missionary" ${ }^{14}$. (WILLIAMS, 1917, p.37)

Atentemos agora para as imagens. Na primeira (foto 1), a do hospital, se observa a paisagem de um largo de uma pequena vila. A foto foi tirada durante o dia, não há sinal de pessoas na imagem. No primeiro plano da imagem, uma grande edificação que seria o hospital construído por Butler, em seguida vê-se a fachada de uma casa e ao fundo estruturas que aparentam ser paredes de outras casas. Embora as suas fachadas estejam impedidas de melhor visualização em razão da existência da copa de uma árvore, as outras construções parecem compartilhar a simplicidade e modéstia de típicas casas do sertão nordestino, com poucas árvores à frente e nos quintais. Modéstia e simplicidade que se destacam ao compararmos com a construção em primeiro plano, o Enoch's Hospital. O olhar do fotógrafo parece querer destacar essa diferença arquitetônica, em razão do ângulo panorâmico. O hospital é em estilo neo-clássico, há um verdadeiro pórtico de entrada com altas colunas jônicas, simetria e imponência típicas da arquitetura colonial americana, com várias janelas frontais e laterais.

A segunda imagem (foto 2) é uma fotografia do missionário George Butler e do Sr. Caetano Vidal. Ambos aparentam cerca de 60 a 70 anos, um indício de que a foto foi feita nos anos 1910 (George Butler nasceu em 1854). Na foto, eles aparentam estar à frente de uma casa, à direita da imagem há uma porta aberta e ao centro, entre os dois retratados, uma janela com grades de ferro e à esquerda uma planta que se assemelha a uma samambaia, peça de decoração comum ainda hoje em alpendres e terraços. Ambos estão com roupas muito semelhantes, típicas de homens de importância social da época: paletó, casaca, gravata e chapéu. Ambos estão sentados, todavia o Sr. Caetano diferencia-se ao segurar uma bengala na mão direita. Igualmente chama atenção a postura diferenciada dos retratados. Enquanto o médico-missionário fixa um olhar sério à máquina fotográfica, o $\mathrm{Sr}$. Caetano dirige um olhar também sério e levemente distraído, em outra direção, próprio da estética das pinturas de autoridades do século XIX, produzindo um ar dignificante ao sujeito.

14 "Durante vinte e um anos Sr. Caetano tem sido um crente, um membro da igreja, um convicto defensor do evangelho, e leal amigo, e heroico defensor do missionário". 


\section{Uma iconografia}

Propomo-nos uma análise por meio dos elementos do "circuito iconográfico". Sobre a produção da foto do Hospital (foto 1), temos a indicação de que ocorreu entre 1916 e 1917 (quando é divulgada pela publicação que tivemos acesso). Em janeiro de 1916, o Dr. Butler em carta ao The Missionary Survey promete: "The hospital is almost finished and I'll send you photo of that as soon as I can get a good artist"15. Essa informação nos ajuda a estimar com certa precisão a época da fotografia do hospital já construído.

Sobre o hospital outro dado importante a considerar e que se extrai do livro de Henry F. Williams, é o fato de que Butler não recebeu nenhum recurso da PCUS, para construir o hospital e nem mesmo a Igreja Presbiteriana de Canhotinho foi construída com recursos eclesiásticos, e sim com a exportação de orquídeas e venda por um amigo em Nova Iorque (WILLIAMS, 1917, p.36). Este desamparo financeiro possivelmente causou certo ressentimento ${ }^{16}$ dos Butlers em relação ao Board de Nashville, talvez, levando-os a faltarem com os relatórios ${ }^{17}$. Até onde pudemos averiguar, de novembro de 1911 a julho de 1915, é

15 “O hospital está quase terminado e eu lhes enviarei uma foto dele assim que eu puder conseguir um bom artista" (The Missionary Survey, Janeiro, 1916, p. 19)

16 Nesse ponto a memória de Dna Rena deixa transparecer um certo conflito com o Board de Nashiville, a ponto de ter de pedir permissão para continuar uma atividade econômica fora das atividades religiosas a fim de prover recursos pelo menos até os filhos terminarem uma faculdade: "Our two sons were beginning their professional education with not enough money to get through. I wrote to the Committee, told them of our difficulty and asked to be allowed to continued the sale of orchids till the boys finished. They give their consent, and booth boys were graduate from the University of Maryland" [Nossos dois filhos estavam começando sua educação profissional sem dinheiro suficiente para completá-la. Eu escrevi ao Comitê, conteilhes de nossa dificuldade e pedi para permitirem continuarmos com a venda de orquídeas até os rapazes terminarem. Eles deram seu consentimento, e ambos rapazes foram graduados pela Universidade de Maryland]. (Dr. George Butler by Mrs Butler, s/d, p.2 e 3, Arquivo da Presbyterian Historical Society, RG 360, series III)

${ }^{17}$ O também missionário Henderlite, em 1913, escreve ao Board de Nashville (órgão de administração missionária da PCUS) sobre Butler: "He keeps no notes of his work, has no session book in his chuch and never gives in a written report to Presbitery. When the Presbitery insists on a statistical report of finances e batisms, he replies that Paul did not remember how many batisms he made in Corinth, and he is no better than the Apostle Paul" [Ele não guarda anotações de seu trabalho, não tem livro de atas na sua igreja e nunca dá relatório por escrito ao Presbitério. Quando o Presbitério insiste sobre uma estatística de finanças e batismos, ele responde que Paulo não lembrava quantos batismos ele fez em Corinto, e ele não é melhor que o Apóstolo Paulo]. ("Our work in North Brazil", The Missionary Survey, Agosto, 1913, p. 755). 
o maior interregno sem notícias dadas pelos próprios Butlers do seu trabalho no Brasil.

Quanto a foto do Dr. Butler e do Sr. Caetano (foto 2), é necessário considerar que depois de julho de 1915 os Butlers parecem mais constantes nos relatórios. Ademais, a narrativa da importância do Sr. Caetano no estabelecimento protestante em Canhotinho aparece somente no relatório escrito pela Dona Rena, publicado em julho de $1916^{18}$, juntamente com uma foto do Sr. Caetano montado num cavalo pampa. Provavelmente esta foto do Sr. Caetano e a que ele está ao lado do Butler (foto 2), a qual analisamos aqui, foram feitas para serem enviadas com os relatórios como parte do esforço dos Butlers de serem mais constantes na prestação de contas de sua atividade missionária no interior brasileiro em nome e com recursos (ainda que parcos) da PCUS. Assim, é plausível que esta foto (foto 2) fora feita no mesmo período a do hospital, talvez, aproveitando o mesmo "bom artista". Resumindo, as fotos acima (foto 1 e 2) foram feitas entre 1916/1917, no contexto de retorno dos Butlers à tarefa de enviar relatórios ao The Missionary Survey. Por fim, em 1917 temos as fotografias enviadas ao Board de Nashville (órgão de administração missionária da PCUS) e publicadas juntas por Henry F. Wiliams, em um livro que sintetiza as ações missionárias da organização no Brasil.

A foto do Sr. Caetano e do Dr. Butler só voltou a ser publicada em 1976, em uma obra biográfica encomendada pela Missão ao Norte do Brasil (à época, braço missionário da PCUS, no Nordeste brasileiro) ao sociólogo e pastor presbiteriano Edijéce Martins Ferreira e intitulada “A Bíblia e o Bisturi”, sobre George Butler. Desta vez, a foto do Enoch's Hospital não aparece nessa obra, apenas uma foto da edificação abandonada com a fachada descaracterizada, nem de longe parecido com antigo hospital de George Butler ${ }^{19}$.

\footnotetext{
${ }^{18}$ Ainda não tivemos contato com todos exemplares do "The Missionary Survey" que era uma revista mensal. A coleção completa só há nos arquivos da PHS, nos Estados Unidos. Existem alguns exemplares no Arquivo Presbiteriano em São Paulo [não há todo os anos e as coleções anuais disponíveis não contém todos os números mensais]. Entre tais, na The Missionary Survey de julho de 1916, encontramos a narrativa em análise. Nas narrativas anteriores sobre a introdução do protestantismo em Canhotinho, fala-se da perseguição sofrida pelos Butler mas não cita o Sr. Caetano Vidal dos Santos.

19 É pouco provável que Edijéce Martins não conhecesse esta foto do Enoch's Hospital com a fachada original, pois o autor teve acesso aos arquivos do PHS sobre o Butler e certamente recebeu o mesmo livro analisado neste artigo. A foto do
} 
Por esse rápido esboço da trajetória dessas imagens, podemos vislumbrar diferentes ressemantizações e também efeitos sobre as diferentes realidades nas quais as próprias imagens passam a fazer parte enquanto coisas a serem manipuladas e reelaboradas nas diferentes historicidades. Podemos captar inicialmente quatro espaçostempo de circulação/apropriação das imagens: $1^{\circ}$ ) dos fiéis contribuintes das igrejas presbiterianas americanas da PCUS em 1917; $2^{\circ}$ ) do contexto das relações "intra pares", de Butler com os demais missionários no Nordeste brasileiro no início do século $\mathrm{XX} ; 3^{\circ}$ ) do contexto das relações de Butler e do Sr. Caetano no campo políticoreligioso que se delineia no período pós-proclamação; e por último, $4^{\circ}$ ) do contexto dos anos 1970, vinculadas as disputas eclesiásticas sobre como representar a memória dos seus pioneiros no conjunto de conflitos e cisões internas às hierarquias da Igreja Presbiteriana de Pernambuco, decorrentes dos alinhamentos e oposições ao regime militar instalado no país desde 1964.

Apesar dos interessantes aspectos deste último "espaço-tempo" de circulação-apropriação das imagens, preferimos, por ora, restringir nossa observação aos usos e apropriações das imagens em seus contextos de produção, circulação e consumo do início do século $\mathrm{XX}$, no Brasil e nos Estados Unidos, relativos ao $1^{\circ}, 2^{\circ}$ e $3^{\circ}$ itens acima.

O $1^{\text {o }}$ espaço-tempo de circulação das imagens concerne aos fiéis da PCUS. Aqui a relação com o texto de Henry F. Williams (1917) nos dá pistas. Ele apresenta os números do crescimento de fiéis, chegando a 300 só do trabalho de Butler em Canhotinho e região; apresenta o número de atendimentos médicos de Butler (mais de 8.500), o custo da construção do Hospital $\$ 5.000$ (cinco mil dólares ${ }^{20}$ ), feita pela generosidade de um amigo metodista; porém, quando fala da construção da Igreja, afirma que "Dr. Butler has always done an immense amount of charity pratice, but he has received from his paid

hospital que o autor publica é já de sua fachada descaracterizada nos anos 1970 . Talvez seu propósito foi destacar para a sua instituição - a Igreja Presbiteriana do Brasil -, a negligência desta para com a memória de George Butler e dos pioneiros do Nordeste.

20 Pela cotação que o próprio Butler realizava em suas cartas à época, aproximadamente 10:000\$000 (10 contos de réis). Esse valor era mais que o quíntuplo do arrecadado no ano de 1919 pela Igreja de Canhotinho - 1:951\$310, segundo os dados financeiros existentes nas Atas do Presbitério de Pernambuco $\left(4^{\circ}\right.$ livro de Atas do Presbitério de Pernambuco, p. 13; disponível no LIBER Laboratório de Tecnologia da Informação - da UFPE) 
pratice sufficiente amount to erct a church and a school building"21 (WILLIAMS, 1917, p. 36), ou seja, oculta que a igreja fora construída com o dinheiro da venda de orquídeas, como é a narrativa dos relatórios de Butler (The Missionary Survey, janeiro, 1916 apud VIEIRA, 1960, ps. 68,69) e na própria carta biográfica da Dna. Rena: "...in Canhotinho we built a church with the sale of orchids" 22 . Ao que parece, a PCUS não via com bons olhos a certa "autonomia financeira" dos Butlers, mas também reconhecia que não tinha como manter seus missionários no campo, daí "consentia" ${ }^{23}$ pela continuidade da venda de orquídeas.

Voltando às fotografias, a iniciativa da PCUS em unificar os relatórios dos missionários no Brasil e organizá-los por região, nessa publicação de 1917, indica um esforço de divulgação dos trabalhos missionários e de mobilização econômica dos fiéis em prol desses trabalhos. A ideia dominante na obra é que pela ação dos missionários (e a imagem do hospital seria emblemática), o atraso e a barbárie do interior do Nordeste brasileiro (atraso este que, segundo a perspectiva dos missionários, a Igreja Romana mantinha e alimentava como forma de dominação do povo) estava sendo invadida pela luz da civilização americana, transplantando suas formas de sociedade e cultura (autonomia individual, racionalidade científica, eficiência, moralidade e progresso etc.). Valores civilizacionais capazes de transformar mesmo a alma dos mais resistentes, como é o caso do Sr. Caetano Vidal, de um chefe local inimigo, pronto a comandar o apedrejamento de um missionário a um "leal amigo e heroico protetor do missionário" (WILLIAMS, 1917, p.37).

As fotografias de Butler e do Hospital articuladas ao texto nos permitem entrever uma forma de conceber aquela obra missionária, a partir do ponto de vista da instituição, a PCUS, como um capítulo do combate entre a civilização e a barbárie. E assim conclamar os fiéis estadunidenses para investirem seus recursos financeiros nesse embate. A imagem do Enoch's Hospital vinculada à imagem do Dr. Butler sentado ao lado do Sr. Caetano potencializam os objetivos de

21 "Dr. Butler sempre fez uma imensa quantidade de medicina de caridade, mas ele tem recebido por seu pagamento de clínica médica quantidade suficiente para erguer uma igreja e um edifício escolar"

22 "Em Canhotinho nós construímos uma igreja com a venda de orquídeas". (Dr. George Butler by Mrs Butler, s/d, p.2. Arquivo da Presbyterian Historical Society, RG 360, series III)

${ }^{23}$ Ver nota 16. 
mobilizar os fiéis a aumentarem suas doações à obra missionária no Brasil, mostrando-lhes o impacto concreto dessa presença missionária em um mundo tão pobre e atrasado econômica, moral e politicamente.

Dessa forma, as imagens visam produzir sentidos aos leitores americanos relativos à dimensão de um embate civilizacional ocorrendo no Brasil. Ou seja, convencê-los de que por trás do que, à primeira vista, poderia ser entendido apenas como um conflito entre igrejas cristãs (católicos X protestantes) por fiéis - o que poderia diminuir a disposição de doar para as missões na América do Sul em prol de áreas não cristãs como África e Ásia ${ }^{24}$-, ocorria uma luta bem mais de fundo no tempo e no espaço, entre o modelo político-social protestante autoindentificado como verdadeiramente democrático, libertador e humanitário e o modelo católico representado (pelo e para os protestantes) como seu antípoda: autoritário, hierárquico, obscurantista e opressor.

Nos dois espaço-tempo seguintes de produção/consumo dessas imagens, isto é, relativo ao contexto das relações "intra pares" de Butler com os demais missionários no Nordeste brasileiro e ao contexto das relações de Butler e do Sr. Caetano no campo políticoreligioso, o reconhecimento do contexto brasileiro da segunda década do século XX e a leitura das cartas de Dona Rena nos fornecem elementos para interpretação.

Após a Proclamação da República e a separação formal entre a Igreja e o Estado, os primeiros conflitos decorrentes das perdas econômicas e políticas da Igreja Católica vão cedendo espaço para uma nova acomodação das relações Igreja-Estado. Com isto a Igreja Católica reconquista parte do seu poder no campo político nas primeiras décadas do século XX, baseada num projeto de integração identitária entre a sociedade/cultura brasileira e a religião católica. O projeto católico propunha a defesa e construção ideológica da "cultura católico-brasileira”, uma harmonização teórica entre o Estado, o Povo

${ }^{24}$ Havia no protestantismo anglo-saxão da segunda metade do século XIX uma crescente ideia de que o catolicismo seria uma descaracterização do verdadeiro cristianismo, mas ainda havia discordantes dessa postura anti-católica - esta defendia que América Latina deveria ser considerada como cristã, portanto, fora dos objetivos missionários mundiais das Igrejas Protestantes -, a ponto dessa questão ser polemizada em dois Congressos Mundiais no início do século XX, Edimburgo (1910) e do Panamá (1916), pendendo a balança negativamente aos católicos (MENDONÇA, 1995, p. 64). 
e a Igreja Católica; ainda que legalmente, para atender aos preceitos modernos do liberalismo, não houvesse religião de estado e fosse garantida a liberdade religiosa. Sanchis esclarece-nos os caminhos dessa construção:

Primeiramente, no fim do século passado e início deste século, quando a Igreja, marginalizada do espaço público, pela separação da Igreja e do Estado, tentava reconquistar seu lugar nessa arena, ela desenvolveu uma ideologia chamada a prolongar-se como difusa construção da identidade nacional. Três monumentos literários encerram a elaboração e expressão inicial desta identidade do Brasil: O discurso programático de Rui Barbosa no Colégio Jesuíta de Nova Friburgo (1903), o "Livro do Centenário" do padre Júlio Maria (1900), e antes até, o documento-fonte que deu asas a essa visão em 1896, as Conferências Anchietanas, convocadas por Eduardo Prado no momento exato em que o Estado começava a dar sinais de um desejo de reaproximação com a Igreja, pela necessidade pressentida de algo como uma "religião civil" para sustentá-lo. (SANCHIS, 1994, p. 146)

(...)

No momento em que ela nasceu, era evidente que as elites brasileiras - intelectuais, políticas e sociais - não eram católicas nem suscetíveis de serem "emblematizadas" pela Igreja. Era, pois, um Brasil popular que a Igreja pretendia (tinha consciência de) representar, emblematizar, corporificar. Frente ao outro Brasil, o das elites, se fosse necessário. (SANCHIS, 1994, p.147)

Por sua vez, o projeto protestante de transplante dos valores culturais americanos buscava se afirmar, não somente pelo proselitismo dos missionários, mas também pela organização de instituições que lhes "garantissem lugares e posições de influência, representatividade e visibilidade", principalmente através da educação, assistência social e organizações ecumênicas (não pertencentes a uma única denominação protestante) como a Associação Cristã de Moços, criada, no Brasil em 1893 (SANTOS, 2006, p. 168). Nesse sentido, o hospital e a escola que George Butler constrói em Canhotinho fazem parte desse objetivo de tornar mais sólidas as contribuições dos missionários para a transformação da sociedade/cultura brasileira na direção dos valores do "American way of life" em obediência ao seu "Destino Manifesto" (MENDONÇA, 1995, p.77). Ademais, como médico e depois da epidemia de febre amarela em Garanhuns e Canhotinho em 1897, George Butler passa a exercer com mais destaque sua profissão de médico e de higienista local e isso principalmente com a colaboração dos políticos locais como no caso do filho do Sr. Caetano que, no início do século XX, tornara-se prefeito de Canhotinho. A narrativa 
que iniciou este texto prossegue, conforme a segunda carta de Dona Rena:

That was the first sermon ever preached in Canhotinho and $\mathrm{Sr}$. Caetano's son was the first convert. This young man stood by me at the organ and led the choir for fifteen years, read the New Testament through with me and recited perfectly the Shorter Catechism. When he became Mayor he was Dr. Butler's intelligent and willing cooperator insanitation and in every measure that was for the good of the town, so that, when Dr. Egbert Smith visited it some years later he said he found a town that looked like it had been transplanted from the United States $^{25}$ (Concerning Dr. George Butler's Work by Mrs Butler, s/d, p.1. Arquivo da Presbyterian Historical Society, RG 360, series III).

Podemos ver que o missionário angariou influência não somente por suas relações pessoais com o Sr. Caetano e família, nem tampouco por sua caridade em atender doentes de todos os lugares, mas principalmente por sua capacidade de implementar transformações concretas na paisagem e saúde pública da cidade, desde o imponente hospital até a sanitarização urbana. Enfim, traz para o plano empírico, nos grotões do interior nordestino, os benefícios da civilização moderna; uma ilha de ordem em meio ao caos de tantas carências e doenças, produto da "miséria", "idolatria" e "superstição" daquela gente sertaneja ${ }^{26}$.

Portanto, vamos às imagens considerando o espaço-tempo dos pares (de Butler e do Sr. Caetano Vidal). Para circulação entre os missionários e ao Board de Nashville: Butler, com essas fotos, respondia à queixa da ausência de relatórios (cuja expressão seria em números de convertidos, igrejas abertas etc.) com uma demonstração clara de seu poder realizador e de sua posição consolidada frente aos poderes locais, exatamente por ser médico, e não somente um pregador. Ademais, podemos considerar que as fotos enviadas para o Board constituíam a percepção que Butler tinha dos caminhos que os missionários no Nordeste deveriam seguir - ainda mais diante da intensificação da reação/oposição católica no período posterior à

${ }^{25}$ Esse foi o primeiro sermão pregado em Canhotinho e o filho do Sr. Caetano foi o primeiro convertido. Este jovem ficou ao meu lado no órgão e liderou o coro por quinze anos, aprendeu a ler o Novo Testamento comigo e recitou perfeitamente o Catecismo Menor. Quando ele se tornou prefeito era um colaborador inteligente e disposto do Dr. Butler na sanitarização e em todas as medidas que eram para o bem da cidade, de modo que, quando o Dr. Egbert Smith a visitou alguns anos mais tarde, ele disse que encontrou uma cidade que parecia ser transplantada dos Estados Unidos

${ }^{26}$ Esses são termos comuns nos relatórios dos missionários da região. 
laicização do $\operatorname{Estado}^{27}$-, isto é, tornar concretas e estáveis as bases da transformação cultural através da criação de instituições de assistência e educação (escolas e hospitais) e construindo seus prédios, diversificando o campo de trabalho e atuação social dos missionários para além da fundação de igrejas e proselitismo.

Por último, vale como exercício imaginativo, pensar a produção de sentidos tanto para o fotógrafo quanto para o Sr. Caetano. O que os leva a legar à posteridade aquela foto, daquela maneira? Inicialmente, parece-nos claro que a foto partiu de uma construção da cena, das poses, do cenário, da vestimenta, possivelmente propostas pelo fotógrafo. O olhar que fotografa é de alguém que procura transmitir a ideia de que se está diante de autoridades: os símbolos de distinção (roupas semelhantes) e de poder (o olhar distante do Sr. Caetano e sua bengala à mão). Isso nos permite deduzir que o fotógrafo era alguém que fazia parte daquele contexto de códigos culturais do interior nordestino. Nesse sentido, para o sujeito que fotografa, não havia ali, diante da câmara, um pastor e um fiel seguidor; a escolha da perspectiva centralizada e a horizontalidade da foto visam transmitir uma relação de equivalência entre ambos, mas a distinção das poses reencena as hierarquias de poder. Aqui, Butler surge apenas como um aliado do velho coronel, bem mais próximo de um agente a serviço do poder local do que um agente eclesiástico. Não estaria aqui uma chave para compreendermos como, naquele momento, o médico-missionário era "lido" pelos aliados locais? Ademais, estendendo o exercício imaginativo, pensemos: o que significa, para o Sr. Caetano, colocar-se ao lado daquele médico-missionário americano?

Estaria a imagem registrando uma oportunidade ao velho coronel de se mostrar como um agente modernizador, ou no mínimo, aliado das forças modernizadoras que se intensificavam desde a chegada da ferrovia à região? Pois eram os capitais e agentes anglo-americanos que traziam transformações substanciais à economia e à paisagem

${ }^{27}$ A reorganização da influência católica sobre a esfera pública, após a proclamação da República, expressou-se em Pernambuco pelas iniciativas de D. Sebastião Leme. D. Leme foi o autor da carta pastoral de 1916, endereçada ao povo de Olinda e Recife, onde lançou as suas idéias sobre a Igreja, e sua influência. Como parte da hierarquia católica ocupou as funções de arcebispo de Olinda e Recife, coadjutor no Rio de Janeiro e cardeal arcebispo no Rio de Janeiro. (VASCONCELOS, 2005, p. 45). Mas já na primeira década republicana surgem demonstrações públicas e organizadas do aumento da hostilidade ao protestantismo em Pernambuco: a organização de "Santas Missões" pelo interior já em 1895 e o surgimento de uma Liga contra os Protestantes em 1902. 
regional. Nesse contexto, as tradicionais oligarquias regionais buscavam se reinventar e pôr-se à negociação e a serviço de forças econômicas e culturais globais que extrapolavam seus controles tradicionais, desde que obtivessem benefícios econômicos e políticos como subsídios agrícolas e certa autonomia do poder local (demandas sempre presentes no pacto entre mandonismos locais e poderes centrais). Dessa forma, esforçavam-se por manter seus poderes através da manutenção do latifúndio, da sub-remuneração da mão-de-obra e do controle do eleitorado sertanejo. Portanto, o Sr. Caetano aliando-se a Butler na foto (assim como no cotidiano) se autorepresenta como um caso bem-sucedido de "modernização sem mudança"28, uma demonstração icônica da capacidade de reelaboração e adaptação dos valores hierárquicos, patrimonialistas e patriarcais aos "novos tempos", às forças de modernização do capitalismo. Dessa maneira, tais inovações (a presença de capitais, imigrantes e de uma religião estrangeiros) não significariam qualquer ameaça a permanência das tradicionais estruturas oligárquicas tais como a desigualdade e a hierarquização da sociedade, a opressão política e social sobre os trabalhadores do campo e das cidades, clientelismo e monopólio do poder baseado na propriedade da terra.

\section{Considerações finais}

Por fim, as imagens que tratamos de analisar nesse artigo nos permitem concluir que, num contexto de crescente tensão, onde forças antagônicas se encontram (a reconquista da nacionalidade pela Igreja Católica, a modernização capitalista da era imperialista na versão anglo-americana, as crises e reações do sistema oligárquico coronelístico local e o interesse de transformar a cultura do povo brasileiro por meio das ações protestantes norte-americanas), a estratégia de George Butler é lançar mão dos recursos sociais e naturais de que dispunha. Imaginando-se em meio a uma sociedade que hostilizava a sua "nova" religião mas, ao mesmo tempo, fragilizada em assistência médica e suscetível à frequentes epidemias,

28 Expressão de Peter L. Eisenberg (1977) para caracterizar como os grandes proprietários de plantações de açúcar, subsidiados pelo governo, se aproveitaram de processos de modernização como a instalação da indústria açucareira através dos "Engenhos Centrais", para "consolidar a própria posição na economia e na sociedade local" (p.17). 
acionou sua identidade profissional para angariar aliados; apresentando-se como um indivíduo portador da racionalidade científica euro-americana e de um humanitarismo civilizador, justificou sua aliança com os coronéis locais ${ }^{29}$ pela atuação como um médico altruísta a serviço do bem comum - o que talvez lhe permitiu certa neutralidade nas disputas oligárquicas locais -, inclusive com a intervenção na paisagem urbana. Para os companheiros de missão, por volta de 1916, era um "ministro" 30 negligente com suas obrigações institucionais e, para o povo a qual atendia, embora sendo um altruísta, possivelmente era como um "igual” aos poderosos proprietários.

Portanto, um indivíduo que em meio às restrições sociais e oportunidades de seu contexto, utiliza-se do que pode para viver em um mundo que considerava pouco "civilizado" e que exatamente por isso, pensando-se como um legítimo representante do "self made man" americano, sentia-se provocado a intervir com transformações materiais e não somente religiosas.

\section{Referências}

EISENBERG, Peter L. Modernização sem mudança: a Indústria açucareira em Pernambuco (1840-1910). Rio de Janeiro: Paz e Terra; Campinas: Universidade Estadual de Campinas, 1977.

FERREIRA, Edijéce M. A Bíblia e o Bisturi. 2 ed. São Paulo: Casa Editora Presbiteriana, 1987.

${ }^{29}$ Numa descrição de uma celebração aos 25 anos de trabalho missionário de Butler no Brasil, em 1908, Miss Eliza Reed expõe assim a estima dos poderosos locais ao Dr. Butler: "Guests came from the state of Alagoas, as well as from towns and plantations of Pernambuco. Leading citiziens of Canhotinho were there too. A comittee, chosen from these guests, presented Dr. Butler with a beautiful ring that is worn by Brasilian physicians" [Convidados vieram de Alagoas, assim como de cidades e plantações de Pernambuco. Lideranças de Canhotinho estiveram lá também. Uma comissão, escolhida destes convidados, presenteou Dr. Butler com um belo anel que é usado pelos médicos brasileiros]. (apud, VIEIRA, 1960, p. 67)

${ }^{30}$ A designação de "ministro" bastante usada por Butler nas atas das igrejas, indica seu status na organização eclesiástica como um agente "autorizado" sem restrições sacramentais, e não um evangelista leigo. Este, como o nome sugere, não tinha a formação teológica necessária, estando restrito seu trabalho à venda de Bíblias e/ou outra literatura evangélica e, às vezes, à pregação em cultos públicos. Butler, embora não tivesse recebido formação teológica e sim médica, foi ordenado "ministro" pela PCUS em 1884 a fim de atender às exigências da lei do Império brasileiro e ao interesse da instituição em estabelecer, por meio dele, um "apostolado médico" no Brasil. 
LÉONARD, Émile-Guillaume. O protestantismo brasileiro: estudo de eclesiologia e história social. 2ed. Rio de Janeiro e São Paulo: JUERP/ASTE, 1981

MATOS S. Alderi. Os Pioneiros Presbiterianos do Brasil (18591900). São Paulo: Cultura Cristã, 2004.

MENDONÇA, Antônio Gouvêa. O Celeste Porvir: a inserção do protestantismo no Brasil. São Paulo: Aste, 1995.

MENEZES, Ulpiano T B. de. Fontes visuais, cultura visual, História visual: balanço provisório, propostas cautelares. Revista Brasileira de História, São Paulo, v. 23, nº 45,p. 11-36, 2003.

SANCHIS, Pierre. O Repto Pentecostal à "Cultura CatólicoBrasileira”. In: Revista de Antropologia, vol. 37, 1994, p. 145-181.

SANTOS, Lyndon de Araújo. As outras faces do sagrado: protestantismo e cultura na Primeira República Brasileira. São Luís: Edufma; São Paulo: Ed. ABHR, 2006.

VASCONCELOS, Micheline R. Os Nova Seitas: a presença protestante na perspectiva da literatura de cordel - Pernambuco e Paraíba. Dissertação (Mestrado em História). PUC-SP, São Paulo, 2005.

VIEIRA, David Gueiros. A Historical Study of the missionary work of Dr. George W. Butler and ananalysis of his influence on Brazil. Dissertação (História). University of Richmond: Virginia,1960.

A trajetória de uma família: a história da família Gueiros. Recife: Nossa Livraria Editora, 2008.

WILLIAMS, Henry F. In Brazil: the brazil missions of the Presbyterian Church in the United States. Richmond, Va.; Texarkana, Ark-Tex: Presbyterian Board of Publication, 1917.

Recebido em 25/10/2015

Aprovado em 30/12/2015 